\title{
Chemical regulation of sex expression in certain olive cultivars
}

\author{
E. S. HEGAZI AND G. R. STINO \\ Department of Horticulture, Faculty of Agriculture Cairo University, Egypt \\ <Received: November $15,1980>$
}

\begin{abstract}
The modifying effect of growth regulators on bud burst, flower bud formation and sex expression in olives varies greatly according to cultivar, concentration and time of application. Cycocel $200,500 \mathrm{mg} / \mathrm{l}$. ethephon $200 \mathrm{mg} / \mathrm{l}$ and SADH $2000 \mathrm{mg} / 1$ stimulated bud burst and flower bud formation in the 'Blanquetta' cv. A noticeable increase in the percentage of perfect flowers was obtained by $100 \mathrm{mg} / 1$ of kinetin*, and $200 \mathrm{mg} / 1$ of Cycocel in the cv. 'Picual', Ethephon 200/l, Cycocel $200 \mathrm{mg} / \mathrm{l}$ and SADH $2000 \mathrm{mg} / \mathrm{l}$ considerably increased the percentage of perfect flowers in the cvs 'Blanquetta', 'Serrana' and 'Picual'. Treatments at green cluster stage were not effective.
\end{abstract}

\section{INTRODUCTION}

Recent reports have given strong evidence for the possibility of modifying sex expression of some plants by certain growth regulators. It was reported that auxins modified sex expression in Cucurbitaceae plants $\langle\mathrm{Wittwer}$ and Hilyer, 1954; Gal u n, 1958; K a u s hik and A ror a, 1969 >. Cytokinin is also of significance in modifying the male flowers to hermaphrodite in ceratin vitis hybrids 〈G a rgiola, 1958; Negi and Ol mo; 1966〉 and in Luffa acutangula $\langle\mathrm{B}$ ose and Nitsch,1970 . Trials concerning this phenomenon have been recently shifted towards the use of ethephon, an ethylene producing agent. Sex expression of monoecious cultivars of Cucurbitaceae was highly influenced by treatment with this chemical <McMurray and Mille r, 1969; G o e r ge, 1970〉. Certain growth suppressing compounds mainly Cycocel $\angle \mathrm{B}$ ose and $\mathrm{N}$ it s ch, 1970; Ghosh and B ose, 1970〉 and SADH $\langle\mathrm{Halevy}$ and R udich, 1967; $\mathrm{B}$ o se and $\mathrm{Nits} \mathrm{ch}, 1970\rangle$ were also reported as agents modifying sex expression in certain plant species.

*Abbreviations: kinetin 〈6-furfurylaminopurine〉, ethephon 〈2-chloroethylene-phosphonic acid $\rangle$, SADH $\langle$ succinic acid 2.2-dimethylhydrazide $\rangle$, Cycocel $\langle 2$-chloroethyl ammonium chloride $\rangle$. 
In olives $\langle$ Olea europea L.>, the ratio of perfect to staminate flowers is a characteristic feature of each cultivar $\langle$ Morettini, 1951〉. The staminate flowers are in fact a hermaphrodite in which the female organ is aborted $\langle$ Hegazi, 1973〉. This phenomenon, however, as related to cultivar, is much affected by a number of environmental and endogenous factors.

The following experiments were aimed at investigation, of the possibility of modifying sex expression in certain olive cultivars by growth substances treatment in favour of differentiating a higher percentage of perfect flowers.

\section{MATERIALS AND METHODS}

The flowering behaviour and sex expression in 20 olive cultivars grown in the orchard of the Faculty of Agriculture Cairo University were previously investigated $\langle\mathrm{He} \mathrm{g} \mathrm{a} \mathrm{z} \mathrm{i,} \mathrm{1973 \rangle .} \mathrm{Three} \mathrm{cultivars} \mathrm{characterized} \mathrm{by} \mathrm{a} \mathrm{low} \mathrm{percentage}$ of perfect flowers were studied in two successive seasons 1972 and 1973. In the first season, three growth regulators, ethephon, Cycocel and kinetin were applied in various concentrations at two different times, January 15 〈prior to flower initiation $\rangle$ and March $20\langle$ at green cluster stage $\rangle$. Three trees $\langle 7$ years old $\rangle$ were chosen from each cultivar. Each growth regulator was applied to a separate tree. Three separate limbs were chosen for various concentrations or control. Aqueous solutions of ethephon and Cycocel were applied till the drip stage. Polyethylene curtains were used to avoid drift of spraying solutions to adjacent limbs. Kinetin solutions were applied by immersing individual shoots in them for one minute. Triton b-1956 〈Rohm Haas Philadelphia 5, PA 〉 was applied in $0.02 \%$ to all used solutions to facilitate absorption.

In the second season, different experiments were designed, taking into consideration the results of the first season. Three growth regulators were used, ethephon, Cycocel, and SADH. Only one concentration of each regulator was used and applied to an individual tree $\langle 3$ replicates $\rangle$. Spraying was conducted on January 1, prior to flower initiation. Forty shoots per treatment were tagged for collecting data concerning the percentage of burst buds in reference to the total number of buds per shoot, the percentage of flower buds, and percentage of perfect flowers in reference to the total number of flowers produced.

The recorded data was subjected to analysis of complete randomized blocks. The significance of mean differences between treatments was determined by the multiple range test $\langle\mathrm{Duncan}, 1955\rangle$.

\section{RESULTS}

The data obtained in the first season indicate that different treatments with Cycocel, ethephon and kinetin dit not significantly increase the percentage of bud burst or flower buds in the cv. 'Picual'. Kinetin in a concentration of $100 \mathrm{mg} / \mathrm{l}$ and 
Cycocel $200 \mathrm{mg} / \mathrm{l}$ significantly increased the percentage of perfect flowers, while the latter considerably reduced this percentage at a concentration of $1000 \mathrm{mg} / \mathrm{l} . \mathrm{In}$ the second season Cycocel 200 and SADH $2000 \mathrm{mg} / \mathrm{l}$ increased the percentage of bud burst and floral buds. The percentage of perfect flowers was considerably higher in treatments with Cycocel $200 \mathrm{mg} / \mathrm{l}$ ethephon $200 \mathrm{mg} / 1$ and SADH 2000 $\mathrm{mg} / 1$ as compared with the control $\langle$ Table 1$\rangle$.

Table 1

Effect of growth substances applied prior to floral initiation on percentage of bud burst, floral buds and perfect flowers in cv. 'Picual'

\begin{tabular}{|c|c|c|c|}
\hline $\begin{array}{l}\text { Treatments } \\
\mathrm{mg} / \mathrm{l}\end{array}$ & Bud burst & $\begin{array}{c}\text { Floral buds } \\
\%\end{array}$ & $\begin{array}{c}\text { Perfect flowers } \\
\%\end{array}$ \\
\hline \multicolumn{4}{|c|}{1972} \\
\hline Cycocel 200 & 59.1 N.S & - & $32.6 \mathrm{a}$ \\
\hline Cycocel 500 & $65.0 "$ & 61.2 N.S & $10.5 \mathrm{bcd}$ \\
\hline Cycocel 1000 & $61.3 "$ & $63.3 "$ & $18.6 \mathrm{ab}$ \\
\hline Ethephon 200 & 69.2 & $61.4 "$ & 2.3 ae \\
\hline Ethephon 400 & $68.1 "$ & $61.5 "$ & $6.4 \mathrm{~cd}$ \\
\hline Kinetin 100 & $62.1 "$ & $68.8 m$ & 33.0 a \\
\hline Kinetin 500 & $71.1 "$ & $61.3 "$ & 5.8 cde \\
\hline Kinetin 1000 & $67.2 "$ & $65.6 "$ & $0.1 \mathrm{e}$ \\
\hline Control & $63.9 "$ & $58.4 "$ & $10.0 \mathrm{bc}$ \\
\hline \multicolumn{4}{|c|}{1973} \\
\hline Cycocel 200 & 35.1 & 26.9 & 79.6 \\
\hline Ethephon 200 & 19.6 & 16.1 & 74.2 \\
\hline SADH 2000 & 31.4 & 28.3 & 66.7 \\
\hline Control & 16.4 & 15.2 & 47.8 \\
\hline
\end{tabular}

Table 2

Effect of growth substances applied prior to floral initiation on percentage of bud burst, floral buds and perfect flowers in cv. 'Blanquetta'

\begin{tabular}{|c|c|c|c|}
\hline $\begin{array}{c}\text { Treatments } \\
\mathrm{mg} / \mathbf{l}\end{array}$ & Bud burst & $\begin{array}{c}\text { Floral buds } \\
\%\end{array}$ & $\begin{array}{c}\text { Perfect flowers } \\
\%\end{array}$ \\
\hline \multicolumn{4}{|c|}{1972} \\
\hline Cycocel 200 & $67.9 \mathrm{ab}$ & $60.9 \mathrm{a}$ & $6.7 \mathrm{~b}$ \\
\hline Cycocel 500 & $69.4 \mathrm{ab}$ & $61.6 \mathrm{a}$ & $5.4 \mathrm{~b}$ \\
\hline Cycocel 1000 & $59.3 \mathrm{bc}$ & $53.0 \mathrm{ab}$ & $6.7 \mathrm{~b}$ \\
\hline Ethephon 200 & $70.2 \mathrm{a}$ & $62.4 \mathrm{a}$ & $49.7 \mathrm{a}$ \\
\hline Ethephon 400 & 55.6 c & $45.8 \mathrm{~b}$ & 50.3 a \\
\hline Control & $56.4 \mathrm{c}$ & $44.9 \mathrm{~b}$ & $23.7 \mathrm{~b}$ \\
\hline \multicolumn{4}{|c|}{1973} \\
\hline Cycocel 200 & 41.2 & 39.7 & 71.3 \\
\hline Ethephon 200 & 54.8 & 48.5 & 73.8 \\
\hline SADH 2000 & 53.5 & 51.4 & 77.5 \\
\hline Control & 30.6 & 35.1 & 42.4 \\
\hline
\end{tabular}


In the cv.'Blanquetta', ethephon at $200 \mathrm{mg} / \mathrm{l}$ and Cycocel at 200 and $500 \mathrm{mg} / \mathrm{l}$ increased the percentage of bud burst and floral buds. The percentage of perfect flowers increased by ethephon at 200 and $400 \mathrm{mg} / 1$. In the second season the percentage of burst buds and floral buds was higher in shoots treated with Cycocel $200 \mathrm{mg} / 1$, ethephon $200 \mathrm{mg} / 1$ and SADH $2000 \mathrm{mg} / 1$ than in the control. The percentage of perfect flowers was increased by treatment with Cycocel 200 $\mathrm{mg} / \mathrm{l}$, ethephon $200 \mathrm{mg} / \mathrm{l}$ and SADH $2000 \mathrm{mg} / \mathrm{l}\langle$ Table 2$\rangle$.

The cv. 'Serrana' was subjected to treatment with Cycocel $200 \mathrm{mg} / 1$, ethephon $200 \mathrm{mg} / \mathrm{l}$ and SADH $2000 \mathrm{mg} / 1$ in the second season. None of these treatments affected the percentage of bud burst or floral buds, while the percentage of perfect flowers was considerably higher in treated shoots in comparison with the control $\langle$ Table 3$\rangle$.

Table 3

Effect of growth substances applied prior to floral initiation on percentage of bud burst, floral buds and perfect flowers in cv. 'Serrana'

\begin{tabular}{|c|c|c|c|}
\hline $\begin{array}{c}\text { Treatments } \\
\mathrm{mg} / 1\end{array}$ & $\begin{array}{c}\text { Bud burst } \\
\%\end{array}$ & $\begin{array}{c}\text { Floral buds } \\
\%\end{array}$ & $\begin{array}{c}\text { Perfect flowers } \\
\%\end{array}$ \\
\hline \multicolumn{4}{|c|}{1973} \\
\hline Cycocel 200 & 35.7 & 34.5 & 90.3 \\
\hline Ethephon 200 & 32.8 & 31.1 & 80.6 \\
\hline SADH 2000 & 41.3 & 27.6 & 99.3 \\
\hline Control & 36.9 & 35.7 & 27.3 \\
\hline
\end{tabular}

\section{DISCUSSION}

Trials on the effect of growth regulators on flowering behaviour and sex expression in olive cultivars comprised treatments conducted either at the time of flower initiation or at the green cluster stage. The obtained results have a preliminary character and open the way for detailed studies in the future. Some effects of growth regulators on bud burst and flower bud formation were obs.rved and this effect was different according to the cultivar and growth regulator used. 'Blanquetta' cv. showed a higher percentage of burst and flower buds after treatments than other cultivars. The percentage of perfect flowers was clearly increased by treatments with kinetin, ethephon, Cycocel and SADH in the cultivars 'Picual', 'Serrana' and 'Blanquetta'. 'Serrana' cv. is a cultivar with an evident tendency to alternate bearing and extremely seasonal variation in the number of perfect flowers $\langle\mathrm{H} \mathrm{e} \mathrm{g} \mathrm{a} \mathrm{zi,1973 \rangle}\rangle$. The general response of cultivars to the treatments was characterized by varietal and seasonal variations. The percentage of perfect flowers was generally higher in the second season with all cultivars than in the first season. The two seasons were considerably different in number of chilling hours as more chilling hours were accumulated in the second 
season during January and February. The average temperature in this period is critical for flower bud differentiation in olives $\langle$ B r ow n et al., 1962〉.

The time of application is a critical factor determining the ability of growth regulators for modifying the structure of flowers. Earlier treatments prior to flower initiation were more effective while late treatments at green cluster stage showed no response.

The role of growth regulators in determining sex and their internal action in plant tissues are largely unresolved. It is known that the internal action of ethephon is confined to ethylene production. Sex expression may be regulated by the hormonal balance of ethylene and other endogenous hormones especially gibberellin which has a contrary effect, as it favours the differentiation of male flowers $\langle\mathrm{Wittwer}$ and Bukovac, 1962〉. It was found that ethephon treatment increased peroxidase and decreased IAA oxidase activity in monoecious cucumber plants. The function of peroxidase and IAA oxidase in cucumber tissues could be explained in relation to growth hormones which determine sex.

There are some indications that Cycocel increases the production of cytokinin by roots $\langle$ Skene, 1968 $\rangle$. This might explain the effect of Cycocel increasing femaleness through its action on the level of cytokinin which is reported as the most powerful agent in producing female flowers $\langle\mathrm{B}$ o s $\mathrm{e}$ and Nitsch, 1970>.

\section{REFERENCES}

Bose T. K., Nitsch G. P., 1970. Chemical alternation of sex expression in Luffa acutangula. Physiol. Plant. 23: 1206-1211.

B rown D. S., Campbell R. C., Schreader W. R., 1962. Temperature and olive yields. Calif. Agric. 16: 7-8.

Duncan D. B., 1955. Multiple range and multiple F test. Biometrics 11: 1-42.

Gargiola A. A., 1958. Change of sex in the wine. The transformation of male flowers into hermaphrodite ones by means of the application of synthetic kinin. Vitis 7: 294-8.

Gal u n E., 1958. The role of auxin in the sex expression of the cucumber. Physiol. Plant. 12: 48-61.

Ghosh M. S., B os e T. K., 1970. Sex modification in Cucurbitaceae plants by using CCC. Phyton B. Aires 27: 1315 .

G oe rge W. L., 1970. Influence of genetic background on sex conversion by 2-chloroethylphoshponic acid in monoecious cucumbers. J. Amer. Soc. Hort. Sci. 96: 152-154.

Ha lev y A. H., R udich Y., 1967. Modification of sex expression in muskmelon by treatment with growth retardants B-995. Physiol. Plant. 20: 1052-1958.

Hegazi E. S., 1973. Sex expression in certain olive cultivars as affected by some growth regulators. Ph. D., Dissertation. Fac. Agric. Cairo University.

Kaushik M. P., A rora P., 1969. The physiology of sex expression in cucumbers. The effect of chemical vernalization. Plant. Sci. 1: 60-8.

McMurray A. L., Miller C. H., 1969. The effect of Ethrel on the sex expression and yields in Cucumis sativus. J. Amer. Soc. Hort. Sci. 94: 400-402.

Morettini A., 1951. A further contribution to the study of ovary abortion in olives. Ann. Sper. Agrar. 5: 309-29. 
Ne gi S. S., Ol mo H. P., 1966. Sex conversion in male Vitis vinifera by a kinin. Sci. 152: 1624-1628. S k e n e K. G. M., 1968. Increases of levels of cytokinin in bleeding sap of Vitis vinifera L. after CCC treatment. Sci. 59: 1477-1478.

Wittwer S. H., Hilyer L. G., 1954. Chemical induction of male sterility. Sci. 120: 893-894.

Wit twer S. H., B u k ova c M. J., 1962. Staminate flowers formation on gynoecious cucumbers as influenced by various gibberellins. Naturwissenschaften 49: 305-306.

\section{Chemiczna regulacja ujawniania się płci u niektórych odmian oliwek}

\section{Streszczenie}

Modyfikujący efekt regulatorów wzrostu na pękanie pąków, tworzenie pąków kwiatowych i ujawnianie się płci u oliwek zmienia się bardzo w zależności od odmiany rośliny oraz stężenia i czasu podania regulatora. Cycocel $200,500 \mathrm{mg} /$, etefon $200 \mathrm{mg} / 1$ i SADH $2000 \mathrm{mg} / 1$ stymulowały pękanie pąków i formowanie się pąków kwiatowych u odmiany 'Blanquetta'. Otrzymano znaczny procentowy wzrost liczby doskonałych kwiatów po zastosowaniu $100 \mathrm{mg} / \mathrm{l}$ kinetyny i $200 \mathrm{mg} / \mathrm{l}$ Cycocelu u odmiany 'Picual'. Etefon $200 \mathrm{mg} / \mathrm{l}$, Cycocel $200 \mathrm{mg} / \mathrm{i}$ SADH $2000 \mathrm{mg} / 1$ spowodowały wyraźny wzrost liczby kwiatów $\langle w \%$ u odmian 'Blanquetta', 'Serrana' i 'Picual'. Zabiegi doświadczalne w stadium zielonych liści nie daly wyniku. 